of the eighteenth century it had begun to develop itself on an enormously great scale, to lands where ground could be obtained at a cheaper rate. In his first research on chlorine Scheele observed its bleaching property, which was carefully investigated by him, only however for theoretical, not for practical purposes. But ten years afterwards the discovery was practically applied by the French chemist Berthollet, who showed that manufacturers possessed in chlorine an invaluable means of giving cloth the desired whiteness by a simple chemical treatment within the manufactory itself. Now for the first time was it possible for the cotton industry to attain the enormous development, the immense social and political importance which the nineteenth century has witnessed. Chloroform and chloral, \&c., are obtained by the action of chlorine on organic substances; by the action of chlorine on lime and potash are obtained chlorides and chlorates-all substances of incalculable importance for theoretical and practical chemistry, for medicine and the arts. Thus in the history of the natural sciences one discovery is linked with another, and the new truth which to-day seems devoid of importance to-morrow becomes a lever for advancing the happiness and well-being of the million.

The second of the works in question is separately printed, first in German, with the title, "Carl Wilhelm Scheele's, d. königl. Schwed. Acad. d. wissenschaft. Mitgliedes,"chemische Abhandlung von der Luft und dem Feuer. Nebst einem Vorbericht von Torbern Bergman, Chem. und Pharm. Prof. und Ritter, verschied. Societ. Mitglied, Upsala und Leipzig," I $777 .^{\text {" }}$ In the introduction, dated I 3 th July, 1777 , Bergman says that the work in question had been ready nearly two years, though various circumstances had delayed its printing, and in a letter to Bergman, preserved in the Library at Upsala, Scheele complains bitterly of the publisher Svederus' procrastination. Various of the most important observations recorded in this work had been already made during the examination of the black oxide of manganese (I 77 I-I774). From all this it follows that Scheele's discovery of oxygen, of nitrogen, ${ }^{2}$ and of the composition of atmospheric air took place simultaneously with Priestley's, and that both these investigators reached the same goal by widely separated paths. Lavoisier too is often, but incorrectly, named as the discoverer of oxygen. On the other hand, it was his genius that laid Priestley's and Scheele's discovery as the foundation for the new and still existing fabric of knowledge. While Scheele and Priestley, ${ }^{3}$ who made the fundamental discovery on which the new theory was founded, remained at the old stand-point, this discovery was estimated by Lavoisier at its true value, and it thus became a veritable turning-point in the history of science. But the numerous ingenious experiments by which Scheele proved the propositions advanced by him at the very beginning of his treatise on "Fire and Air," that the air is composed of two different gases, still to this day are the corner-stones in the new fabric of science, and most of them are still repeated in every series of lectures on the subjects in question.

Death broke off Scheele's scientific path the same year that the work was printed in which Lavoisier distinctly rejected the phlogiston theory, and three years before the first edition of his "Traité Élémentaire de

\footnotetext{
I Most- of Scheele's works were first printed in the Transactions of the Swedish Academy of Sciences, but were immediately after translated into foreign languages. After his death his collected works were published in Latin under the title "Opuscula Physica et Chemica," Lipsia, I788-89 His short papers, in which important discoveries are often stated and proved in a few lines, are complete masterpieces, not only in respect of their contents, but also of their form and mode of exposition. "Ses mémoires sont sans modèle comme sans imitateurs!" (Dumas' "Philosophie Chémique," p. 96.) 2 The Scotch physician Daniel Rutherford has also great credit in connection with the discovery of nitrogen. He showed in $177^{2}$ that a species of gas, which could not maintain combustion, remained after the carbonic acid was withdrawn by means of a solution of caustic potash from the air expired by animals. Rutherford however did not carry out any further investigation of the nature of this gas.

3 Priestley says in his last work, "Mr. Scheele's discovery was certainly" independent of mine, though I believe not made quite so early."
}

Chimie, présenté dans un Ordre Nouveau, et d'après les Découvertes Modernes" appeared. If a prolonged activity had been granted him, if he had made acquaintance not only with isolated propositions from the new theory, but with the fully-developed and completed system, would he have adopted the new theory, and with it as a starting-point gone forward to new and splendid victories in the field of research, or would he, like Priestley, have obstinately stood by the old views? To this question no positive answer can of course be given. But the whole direction of Scheele's activity as a man of science tells in favour of the former alternative, and even much in his peculiar theories which, if we except his attempt to include heat among chemical substances, have many points of contact with current ideas. One thing in any case is certain. He has done enough to earn a place in the first rank of the men of science of all times and of all lands, and his name shall always form one of the grandest memories of his native country.

\section{THE UNITED STATES WEATHER MAPS, APRIL TO JULY, 1878}

THIS week we have the pleasure of presenting our readers, by the courtesy of General Myer, with the International Weather Map for July 1878 , showing for that month the mean pressure, temperature, force, and prevailing direction of the wind. This is the fourth consecutive number of the series, which began with April of that year, and may be regarded as completing the record of the great outstanding features of those changes which characterised the weather of the northern hemisphere in its transition from the spring to the summer of $1878 .{ }^{1}$ We shall here chiefly consider the departures from the averages deduced from the curves and figures of the Weather Maps, seeing that these well represent the great seasonal movements of the atmosphere, together with those meteorological conditions which rule the changes of weather occurring in the different regions of the globe on which the welfare and prosperity of nations so intimately depend.

The map for April showed very large deviations from the average atmospheric pressure in all quarters of the globe. Pressure was under the average over North America, Greenland, the Atlantic to south of Iceland, the north of Africa, over Europe south of a line drawn from the north of Scotland to the Sea of Azov; over the valley of the $\mathrm{Obi}$ and southwards to lat. $40^{\circ}$; over New Zealand and Australia, and northward to the Philippines; and probably also over a large part of the Indian Ocean, including Mauritius and the eastern part of South Africa. Elsewhere pressure was in excess of the average, but most markedly over the north and east of Europe, and the whole of Asia had a pressure above the normal, except the narrow patch already referred to in the extreme west of Siberia and Turkistan.

Of these disturbances in the distribution of the earth's atmosphere, by far the most remarkable was the depression in the heart of the Atlantic, midway between Spain and New York, which amounted nearly to half an inch. Round and in upon this area of low pressure the wind blew in the usual way, bringing warmth to the region lying to eastward and cold weather to regions lying to westward. On proceeding westward pressure rose, till on the coast of the United States it was only about the sixth of an inch below the normal; but proceeding further in a north-westerly direction through the region of the Lakes, the depression gradually again deepened, till near I ake Winnipeg it fell to full a quarter of an inch below the average. The result to the States was an unusual prevalence of southerly winds, a large rainfall for this spring month, and a temperature everywhere high for the season, rising in the N.W. States to $10^{\circ} \cdot 6$ above the ayerage.

I These Weather Maps have appeared in NATURE as follows:-April, No 535 , May, No. $53^{3}$ and June, No. 543 . 
Reverting to the great depression in the Atlantic, we see that it became gradually less and less on proceeding eastward, till at Gibraltar it had risen nearly to the average pressure of April ; but from this point through the Mediterranean a secondary depression was formed, which was deepest over the region lying between, and inclusive of, the Adriatic and Black Seas. Over this region temperature was only the average, whereas to northward temperature rose above the average, the highest excess, $5^{\circ} \cdot 6$, occurring in the south of Norway, which was just within the anti-cyclone area of high pressure. To the eastward of the area of low pressure in Western Siberia the temperature rose to $4^{\circ} .4$ above the average, but along the slopes of the Ural Mountains to westward it was only the average, or even slightly below it.

In May pressure in the United States rose to about the normal in the north-western prairies, but eastward it was lower. The lowest depression, $0^{\circ} 070 \mathrm{inch}$, was about Lake Superior, to west of which, winds being in consequence north-westerly, temperature fell to from $3^{\circ} \circ$ to $5^{\circ} \cdot 2$ below the normal, whilst in the Gulf States, winds being southerly, temperatures ranged from $0^{\circ} \cdot 5$ to $2^{\circ} \cdot 5$ above the average.

The great barometric depression in mid-Atlantic, which was so pronounced a characteristic of the meteorology of April, moved northwards in May to a position immediately to west of Jreland, and was still fully a third of an inch below the average. Between these barometric depressions in the United States and the Atlantic an area of high pressure wedged its way southwards from Greenland, and another high pressure area forced its way northwards from mid-Atlanicic about lat. $30^{\circ}$, these two areas being each about a tenth of an inch above the normal. The influence of this distribution of the pressure was a temperature from $I^{\circ} \circ$ to $3^{\circ} \circ$ above the normal over the British Isles and Western Europe, a lowering of the temperature $2^{\circ .} 5$ below the normal in Iceland, ar, as regards the New England States, a lowering of the high temperature which had prevailed in April to the average in May.

The low pressure overspread the whole of Europe and the northern slopes of Asia, as far to eastward at least as the Yenisei, except the northern shores of the Mediterranean and a long narrow patch extending from the Black Sea to Riga. A secondary depression was formed in the basin of the Obi and its tributaries, its centre being 0.125 inch below the normal. On the east side of this depression, along the Irtish and Yenisei, temperature rose from $4^{\circ} .5$ to $6^{\circ} .6$ above the average of May, whereas to westward, as at Moscow, it fell to $3^{\mathrm{c}} \cdot \mathrm{o}$ below the mean. Thus these barometric depressions in Western Siberia during April and May were fraught with important consequences to the agricultural interests of a large portion of the Russian Empire, extending from the Vistula to the Yenisei.

The three barometric depressions, viz., those in the United States, in the Atlantic west of Ireland, and in Siberia, were merely centres of increased depression within a wide general depression encircling more than half the globe. From the shores of California eastward through the United States, the North Atlantic, the north of Europe and Asia to the basin of the Yenisei, there stretched a continuous broad region of low pressure; and it may be added that so far as observations show, another line might be drawn marking out also a continuous low pressure area extending from the Yenisei, through Turkistan, Syria, Egypt, Zanzibar, and Natal, to the Cape. At the same time pressure was above the average over India and Eastern Siberia ; but the greatest rise of pressure had taken place in Australasia, so that whilst in April pressure was 0.298 inch below the normal in the south-east of New Zealand, in May it was $0^{\circ} 122$ inch above it at Wellington, the increase from the one month to the other being thus $0^{\circ} 420$ inch.
Some important changes in the great movements of the atmosphere were brought about in June. Pressure increased over the North-Western States and Western prairies, but the greatest depression below the average was now found over the Gulf and Atlantic States, with the inevitable result of a weakening of the southerly winds of June, an increase of north-westerly, and a lowering of the temperature everywhere, except in the Gulf States, the greatest depression of the temperature being $5^{\circ} .6$ at Washington. The area of high pressure in the Atlantic increased a tenth of an inch and moved westward about I $5^{\circ}$ of longitude, and at the same time extended in area; the high pressure noted in Greenland in May now covered a wider extent and moved eastward, the greatest excess above the mean being 0.170 inch in the east of Iceland. The high pressure that lay between the Black Sea and Riga now extended westward to Switzerland and eastward to the upper reaches of the Yenisei. The temperature changes accompanying these great atmospheric movements were a slight lowering of the temperature below the average over the whole of Central Europe, the south-west of Norway, and the east of Scotland, and the raising of the temperature of the whole of the Russian Empire above the average, the excess in the valley of the Kama being $6^{\circ} .5$, and from the Sea of Azov to the head of the Caspian $6^{\circ} .8$. Pressure at the same time fell to some extent under the average along the Mediterranean and north of Africa round to Cape Verd Islands, a change intimately connected with the lowering of the temperature which set in to the northward over Central Europe.

Pressure continued low over Southern and South-Eastern Africa and in Mauritius, though relatively not so low as in the previous months; and it had again fallen greatly in Victoria, Tasmania, and New Zealand. The deficiency in the latter islands amounted to 0.429 inch, being a relative fall in the mean pressure as compared with May of 0.561 inch.

In India pressure in the west still continued above the average, the excess at Kurrachee being 0.050 inch; but in the east it had gone below the normal at Visagapatam, stood near the average at Port Blair, and at little below it at Manila. As regards this part of the globe, the meteorological position in June was this ; except a narrow patch of higher pressure extending from the mouth of the Indus southward over the west of India, and thence south-eastward through Singapore and Batavia to Adelaide, South Australia, pressure would appear to have been under the average from Cape Verd Islands, round by the Mediterranean, Black, Caspian, and Aral Seas, Tashkent, Shanghai, New Zealand, Australia and the Cape.

In July pressure was under the normal in the United States and Greenland, with two centres of greater depression, one in the north of Greenland and the other about the Rocky Mountains south of lat. $40^{\circ}$. The influence of this arrangement of pressure, as regards the United States, was an increased prevalence and strength of southerly winds to east of the Rocky Mountains, accompanied with a temperature from one to three degrees above the average of July, and a rainfall considerably above the average; whereas on the Pacific coast N.W. winds were in excess, and the temperature in Oregon was $2^{\circ} .7$, and at San Diego $1^{\circ} \circ$ o below the mean.

From the north coast of South America, and thence stretching to north-east as far as the north of Iceland and Christiansund in Norway, lay a broad extensive region of very high pressure, embracing within its northern limits the whole of the British Isles, the north of France, Belgium, Holland, and a thin strip of the southwest of Norway, the centre being in mid-Atlantic about lat. $35^{\circ}$ and long. $35^{\circ}$. In the British Islands temperature was above the average, the greatest excess being $2^{\circ} .8$ in the north of England.

Another extensive area of pressure, above the July average, overspread India and extended towards the north-east, 
round by Barnaul, Irkutsk, Nerchinsk, Pekin, Shanghai, and Port Blair, whereas over the East India Islands, New Zealand, Tasmania, Australia, Mauritius, and the east of Africa, so far as observations supply information, pressure was under the average, and very largely so over the whole of the southern portions of this wide-spread region.

Between the high pressure of the North Atlantic and the relatively high pressure of Southern Asia, there was interposed an extensive tract of low pressure, stretching from Portugal to the Yenisei, and from Egypt to the North Cape, having its centre $0^{\circ} 244$ inch below the average near Moscow. To the east of the Ural Mountains temperature rose to $4^{\circ} \cdot 3$ above the average ; but on the west side of this depression temperature was $5^{\circ} \circ$ at Warsaw and $8^{\circ} .5$ at Kem, west of the White Sea, below the average of July.

A striking feature of the distribution of the earth's atmosphere in July 1878 , is the enormous breadths over which pressure was below the average, and the comparatively restricted regions over which it stood above the average. An explanation of this seeming anomaly is furnished however by the figures on the map for July, which presents for the first time a monthly mean for the centre of the Pacific Ocean. This mean is from the Sandwich Islands, and shows an excess there above the normal for July, amounting to the large figure of 0.300 inch.

Thus then the meteorology of the globe for July 1878 , stands out as a singular phenomenon, characterised by these broad features, viz. :-(I) a greatly reduced pressure over a large portion of the Southern Hemisphere as contpared with what usually obtains there in the winter month of July; (2) a much greater diminution of the pressure than usually takes place in the summer month of July over the land of the Northern Hemisphere, over North $\Lambda$ merica, over Central and Eastern Europe, Western and Central Siberia; and (3) a much larger increase of pressure than usually occurs in the Northern Hemisphere over the great oceans in July, the area of unusually high pressure being extended, as regards the Atlantic to the north-east as far as Christiansund, and as regards the Pacific to westward over Central and Southern Asia, as far as the Arabian Sea. It may be worth remarking that this increased pressure over the oceans and diminished pressure over the land of the Northern Hemisphere is in accordance with what might be expected to result from an increased solar radiation ; whilst on the other hand the increased pressure over Southern and Central Asia, and diminished pressure in the Southern Hemisphere, is not in direct accordance with this supposition. The point here referred to will however receive an illustration from subsequent num bers of the Weather Maps, by which it is probable that different results as regards the states of the atmosphere will appear, with the varying states of the sun from year to year.

The future maps of this international series will be eagerly scanned in connection with many of the larger questions of atmospheric physics, as well as those directly practical questions of climate with which we have been almost exclusively concerned in this article. It is plain that we need not hope to succeed in dealing with most of the larger problems proposed by meteorology without the help of the data laid before us in so full and convenient a form by the International Weather Maps of General Myer. It is only thus that we can trace to their proximate causes such climatal phenomena as the recurring droughts of India and the cold, sunless summer of the British Islands in I 879, and show their true relations to the great movements of the atmosphere. For this great work the highest praise must be conceded to General Myer, whose genius struck out this cosmopolitan scleme of observation, and whose powers of organisation and determination of will bore down all obstacles which stood in the way of its realisa- tion; and he has the heartiest wishes of all for its more complete extension over British North America, Sout? America, Africa, and among the islands of the Pacific.

WILLIAM SHARPEY M.D., F.R.S.

$D$ R. SHARPEY, whose death we regret to announce took place on Sunday, was born April I, I 802 . He entered on the study of medicine at the University of Edinburgh in 1818 . In the autumn of 1822 he came to London, where he spent three months in dissecting, and then proceeded to Paris, and occupied the following winter in the study of clinical medicine and surgery in the bospitals. In 1823 he graduated in Edinburgh, and subsequently was for a short time engaged in the practice of his profession in his native town, Arbroath. Soon afterwards he appears to have changed the plan of his life, and for the purpose of educating himself for the scientific career which he had resolved to adopt, he proceeded to the Continent. After spending several months, which were devoted to general culture, at Rome, Naples, and Florence, he resumed the study of anatomy at Pavia, under Panizza. The following years were spent partly in Edinburgh, partly in Paris, Vienna, Heidelberg, and Berlin. At Berlin he became the pupil and friend of Rudolphi, and by laborious anatomical studies laid the foundation of his future success and eminence. In I831 he began to lecture in Edinburgh on anatomy, having his friend Prof. Allen Thomson as his associate; and in 1836 was invited by the Council of the University of London, now University College, to accept the Chair of Anatomy and Physiology, which he occupied until 1874 .

It was about this time that he was most actively engaged in physiological investigation. His scientific writings, which were not numerous, have the characteristic excellences of accuracy of observation and soundness of judgment. One of his earliest contributions was on ciliary motion, and appeared in 1830 . Others formed the subjects of articles in the "Cyclopædia of Anatomy and Physiology," while a still greater number were embodied in the successive editions of the "Elements of Anatomy." Notwithstanding the rapid progress of anatomical and physiological science during the past thirty years, none of Dr. Sharpey's observations have lost their value.

He was appointed Secretary of the Royal Society in 1854, shortly after important changes had taken place in its administration, in the bringing about of which he, with others whose names are not less distinguished, had taken part. The beneficial effect of these changes in extending the Society's influence for the advancement of natural science was due in great measure to the sagacity and energy with which he administered such of its affairs as fell within the scope of his duties-duties for which he was singularly fitted by the extent and variety of his learning, by the wisdom of his counsels, by the wide range of his scientific interests, by the candour and justice which guided him in appreciating other men's work, and by his ready sympathy with every true and honest worker.

Great as Dr. Sharpey's services to science were in his public capacities as Secretary of the Royal Society, as a Member of the Senate of the University, and of the Royal Commission on Science, and in other ways, these were perhaps not the most important. For years he was the greatest teacher of anatomy and physiology in this country, occupying a position side by side with Johannes Müller in Germany. Just as the influence of Jobannes Müller's life and teaching is still powerful in that of his pupils, so we may confidently anticipate that Sharpey's work will follow him. Of the fellow-workers in his own field who are at this moment mourning his loss there is perhaps not one who does not directly or indirectly owe him that which has made him what he is; nor should we be far wrong if we were to add that those who are best endowed owe him most.

While the very sounds of our friend's voice are freshly 